\title{
FAKTOR DETERMINAN ANEMIA SANTRI PUTRI
}

\section{DETERMINANT FACTORS OF ANEMIA FEMALE SANTRI}

\author{
Azizatul Hamidiyah', Lutfiatur Rohmani, Nurul Alfiyatuz Zahro \\ Prodi D III Kebidanan, Fakultas Ilmu Kesehatan, Universitas Ibrahimy \\ 1Email: azizatulhamidiyah@ibrahimy.ac.id
}

\begin{abstract}
ABSTRAK
Anemia merupakan masalah kesehatan masyarakat yang banyak terjadi.Remaja putri memiliki risiko sepuluh kali lebih besar untuk menderita anemia dibandingkan dengan remaja putra. Berdasarkan hasil laporan general check up yang dilakukan oleh Unit Penelitian dan Pengabdian Masyarakat Akademi Kebidanan Ibrahimy pada Desember 2016 menunjukkan bahwa 63 santri (52\%) dari 121 santri yang melakukan pemeriksaan $\mathrm{Hb}$ mengalami anemia dengan kadar Hb kurang dari $12 \mathrm{~g} / \mathrm{dL}$. Bahkan 5 dari 63 santri yang mengalami anemia memiliki $\mathrm{Hb} 5 \mathrm{~g} / \mathrm{dL}$. Tujuan penelitian ini untuk menganalisis faktor determinan anemia pada santri Pondok Pesantren Salafiyah Syafi'iyah Sukorejo Situbondo Tahun 2017. Desain penelitian yang digunakan adalah crossectional dengan metode kuantitatif. Penelitian dilakukan pada Desember 2017-Maret 2018 berlokasi di Pondok Pesantren Salafiyah Syafi'iyah Sukorejo Situbondo. Sampel dalam penelitian ini sejumlah 140 santri putri di asrama pusat. Teknik pengambilan sampel dilakukan dengan purposive sampling dengan kriteria inklusi dan ekslusi. Instrumen penelitian menggunakan kuesioner, lembar observasi, dan set HB Check. Analisis data dilakukan secara univariat. Hasil penelitian menujukkan bahwa mayoritas santri menderita anemia sebesar 79\%. Karakteristik sosial ekonomi (jumlah kiriman) santri mayoritas dalam kategori cukup sebesar $66 \%$. Pengetahuan santri tentang anemia mayoritas dalam kategori baik sebesar 49\%. Sikap santri tentang anemia mayoritas dalam kategori cukup sebesar 56\%. Konsumsi gizi santri mayoritas tidak sesuai AKG sebesar 94\%. Pola makan santri mayoritas tidak menentu sebesar $42 \%$. Indeks masa tubuh santri mayoritas dalam kategori normal sebesar 75\%. Pola menstruasi santri mayoritas dalam kategori normal sebesar 52\%. Mayoritas santri selama satu bulan terakhir mengidap penyakit infeksi sebesar 64\%. Aktivitas fisik santri mayoritas dalam kategori ringan sebesar $85 \%$.
\end{abstract}

Kata Kunci : Anemia, Faktor Determinan, Santri Putri, Remaja

\section{ABSTRACT}

Anemia is a public health problem that occurs a lot. Teenage girls have a risk ten times greater for anemia than young men. Based on the results of the general checkup report conducted by the Ibrahimy Midwifery Academy Research and Community Service Unit in December 2016 showed that 63 santri (52\%) of 121 santri who underwent Hb experience anemia with Hb levels of less than $12 \mathrm{~g} / \mathrm{dL}$. Even 5 out of 63 santri who have anemia have $\mathrm{Hg} 5 \mathrm{~g} / \mathrm{dL}$. The purpose of this study was to analyze the determinant of anemia in santri of the Salafiyah Syafi'iyah Sukorejo Situbondo Islamic Boarding School in 2017. The research design used was cross-sectional with quantitative methods. The study was conducted on December 2017-March 2018 located at the Salafiyah Syafi'iyah Sukorejo Islamic Boarding School in Situbondo. The sample in this study was 140 female santri in the central dormitory. The sampling technique was carried out by purposive sampling with inclusion and exclusion criteria. The research instrument used questionnaires, observation sheets, and HB Check sets. Data analysis is done univariately. The results showed that the majority of santri suffered anemia by 79\%. The socio-economic characteristics (number of submissions) of the majority of students in the category were $66 \%$. The knowledge of santri about anemia was mostly in the good category of 49\%. The attitude of the santri about anemia was mostly in the sufficient category of 56\%. The majority of santri's nutritional consumption is not in accordance with the AKG of $94 \%$. The majority of santri eating patterns are erratic at $42 \%$. The majority of the santri body mass index is in the normal category of $75 \%$. The majority of santri menstrual patterns are in the normal category of 52\%. The majority of santri during the past month had an infectious disease of $64 \%$. The majority of santri's physical activity in the light category is $85 \%$.

Keywords: Anemia, Determinant Factors, Female Santri, Teenage Girls 
PENDAHULUAN

Anemia merupakan masalah kesehatan masyarakat yang banyak terjadi dan tersebar di seluruh dunia terutama di negara berkembang. Anemia merupakan suatu keadaan dimana komponen di dalam darah yaitu hemoglobin $(\mathrm{Hb})$ dalam darah jumlahnya kurang dari kadar normal. Remaja putri memiliki risiko sepuluh kali lebih besar untuk menderita anemia dibandingkan dengan remaja putra. Remaja putri juga lebih rawan terkena anemia dibandingkan anakanak dan usia dewasa karena remaja berada pada masa pertumbuhan yang membutuhkan zat gizi yang lebih tinggi termasuk besi. Remaja putri mengalami peningkatan kebutuhan besi karena percepatan pertumbuhan (growth spurt) dan menstruasi (Lynch, 2000). Selain itu, remaja putri biasanya sangat memperhatikan bentuk badan, sehingga banyak yang membatasi konsumsi makan dan melakukan pantangan terhadap banyak makanan (Sediaoetomo, 1992).

Anemia yang terjadi pada remaja maka dapat menyebabkan dampak keterlambatan pertumbuhan fisik, gangguan perilaku, emosional. Hal ini dapat mempengaruhi proses pertumbuhan dan perkembangan sel otak sehingga dapat menimbulkan dampak daya tahan tubuh menurun, mudah lemas dan lapar, konsentrasi belajar terganggu, prestasi belajar menurun serta dapat mengakibatkan produktivitas kerja yang rendah. Bila keadaan akut, keadaan anemia dapat menyebabkan kematian. Anemia yang terjadi pada remaja putri juga merupakan risiko terjadinya gangguan fungsi fisik dan mental, serta dapat meningkatkan risiko terjadinya gangguan pada saat kehamilan nantinya (Sediaoetomo, 1992). Menurut Yip (1998) status besi harus diperbaiki pada saat sebelum hamil yaitu sejak remaja sehingga keadaan anemia pada saat kehamilan dapat dikurangi.

$\begin{array}{rrr}\text { Menurut } & \text { World } & \text { Health } \\ \text { Organization } & \text { (WHO) } & \text { (2013), }\end{array}$
prevalensi anemia dunia berkisar 40$88 \%$. Berdasarkan data hasil Riskesdas tahun 2013, prevalensi anemia di Indonesia yaitu 21,7\% dengan penderita anemia berumur 1524 tahun sebesar 18,4\% (Kemenkes RI, 2013). Data Survei Kesehatan Rumah Tangga (SKRT) tahun 2012 menyatakan bahwa prevalensi anemia remaja putri usia 10-18 tahun sebesar $57,1 \%$ dan usia 19-45 tahun sebesar 
39,5\%. Wanita mempunyai risiko terkena anemia paling tinggi terutama pada remaja putri (Kemenkes RI, 2013). Berbagai survey yang dilakukan kepada siswa sekolah di Indonesia menunjukkan prevalensi anemia sebesar 36\%-43\% (Astuti \& Rosidi, 2014).

Secara umum tingginya prevalensi anemia disebabkan oleh beberapa faktor diantaranya rendahnya asupan zat besi dan zat gizi lainnya seperti vitamin $\mathrm{A}, \mathrm{C}$, folat, riboplafin dan B12 (Briawan, 2014). Anemia juga dapat disebabkan oleh kehilangan darah, diare, konsumsi makan yang tidak adekuat, keadaan tertentu seperti kebutuhan besi yang meningkat pada masa pertumbuhan, menderita penyakit seperti. Faktor lain yang berhubungan dengan anemia adalah defisiensi vitamin $\mathrm{A}$, tinggi badan, ketersediaan besi dalam tubuh, tinggi badan, dan pendapatan keluarga (Bhargava, 2001). Penelitian yang dilakukan Antelman, et al. (2000) dan Asyiqin (2015) menunjukkan ada hubungan yang signifikan antara Indeks Massa Tubuh (IMT), konsumsi sayuran, dan kadar serum retinol dengan anemia. Hasil penelitian yang dilakukan Farida
(2007), Gunamatningsih (2007) dan Listiana (2016) menunjukkan bahwa ada hubungan pendapatan keluarga, pendidikan orang tua, kebiasaan minum teh, indeks massa tubuh, pengetahuan, sikap, pola menstruasi, kejadian infeksi dan tingkat konsumsi gizi dengan kejadian anemia.

Berdasarkan hasil laporan general check up yang dilakukan oleh Unit Penelitian dan Pengabdian Masyarakat Akademi Kebidanan Ibrahimy pada Desember 2016 menunjukkan bahwa 63 santri (52\%) dari 121 santri yang melakukan pemeriksaan $\mathrm{Hb}$ mengalami anemia dengan kadar Hb kurang dari 12 g/dL. Bahkan 5 dari 63 santri yang mengalami anemia memiliki $\mathrm{Hb} 5 \mathrm{~g} / \mathrm{dL}$. Banyak faktor yang menyebabkan hal tersebut terjadi. Asupan gizi santri yang tidak dapat dikontrol karena santri bebas memilih menu makanan dari warung pesantren, bebas dalam menentukan frekuensi makan dalam sehari. Rasio luas warung dengan jumlah santri yang belum ideal sehingga memperpanjang waktu antri dalam memesan makanan. Selain itu, adanya kebijakan santri untuk membawa wadah setiap akan membeli nasi menyebabkan kebanyakan santri enggan membeli nasi dan 
memilih untuk membeli jajanan yang belum memenuhi asupan zat gizi karena malas untuk mencuci wadah setelah makan. Aktivitas padat sejak pukul 03.00 sampai pukul 22.00 juga turut membuat santri lebih memilih meninggalkan jam makan untuk sekedar antri kamar mandi atau melanjutkan aktivitas lainnya.

Tujuan penelitian ini untuk mengetahui faktor determinan anemia pada santri Pondok Pesantren Salafiyah Syafi'iyah Sukorejo Situbondo Tahun 2018.

\section{METODE PENELITIAN}

Penelitian ini merupakan penelitian kuantitatif dengan desain penelitian cross sectional. Lokasi penelitian di Asrama pusat Pondok Pesantren Salafiyah Syafi'iyah Sukorejo Situbondo selama 4 bulan yaitu Desember 2017-Maret 2018. Populasi penelitian ini adalah seluruh santri asrama pusat putri Pondok Pesantren Salafiyah Syafi'iyah Sukorejo Situbondo.

Sampel pada penelitian ini adalah santri asrama pusat putri pondok pesantren salafiyah syafi'iyah sukorejo situbondo meliputi asrama pusat sebanyak 140 santri dengan teknik non probability sampling (purposive sampling).Sampel dalam penelitian ini memiliki kriteria inklusi dan eksklusi.

Data yang dikumpulkan dalam penelitian ini berupa data primer. Data dalam penelitian ini didapatkan melalui wawancara kuisioner, metode recall gizi dan penilaian aktivitas fisik selama 2x24 jam pada $\mathrm{H}-1$ dan $\mathrm{H}-3$, dan pengecekan keadaan $\mathrm{Hb}$ dalam darah menggunakan larutan Copper Sulfate.

Instrumen yang digunakan dalam penelitian ini adalah kuesioner untuk variabel independen meliputi sosial ekonomi, kebiasaan makan, penyakit infeksi, pengetahuan, sikap, pola menstruasi. Lembar isian untuk aktivitas fisik dan recall konsumsi gizi. Software Nutri survey untuk melihat kandungan gizi responden. Timbangan berat badan dan alat tinggi badan untuk mengukur IMT. Serta larutan copper sulfate, blood lancet, alcohol swab dan setets darah untuk menentukan keadaan anemia.

Instrumen dalam penelitian menggunakan instrumen menyadur pada instrumen Farida (2007) yang telah dilakukan uji validitas dan reliabilitas dan terbukti valid ( $\mathrm{r}$ hitung > r tabel 0,306) dan reliable (nilai alpha > $0,60)$. 
Variabel pada penelitian ini adalah sosial ekonomi, IMT, kebiasaan makan, pengetahuan, sikap, pola menstruasi, konsumsi gizi dan aktivitas fisik, penyakit infeksi dan anemia.

Analisis data penelitian ini dilakukan dengan menggunakan uji univariat semua variabel dengan cara membuat tabel distribusi frekuensi, diantaranya variabel sosial ekonomi, IMT, kebiasaan makan, pengetahuan, sikap, pola menstruasi, konsumsi gizi dan aktivitas fisik, penyakit infeksi dan variabel anemia.

\section{HASIL DAN PEMBAHASAN}

Hasil penelitian ini sebagaimana pada Tabel 1 dan Tabel 2.

\begin{tabular}{|c|c|c|}
\hline $\begin{array}{c}\text { Karakteristik } \\
\text { Responden }\end{array}$ & $\mathbf{N}$ & $\%$ \\
\hline \multicolumn{3}{|l|}{ Usia } \\
\hline$\leq 16$ Tahun & 75 & 54 \\
\hline$>16$ Tahun & 65 & 46 \\
\hline Total & 140 & 100 \\
\hline Pendidikan & $\mathbf{N}$ & Usia \\
\hline SMP & 32 & 23 \\
\hline SMA/K & 86 & 61 \\
\hline PT & 22 & 16 \\
\hline Total & 140 & 100 \\
\hline $\begin{array}{l}\text { Sosial Ekonomi } \\
\text { (Jumlah Kiriman) }\end{array}$ & $\mathbf{N}$ & $\%$ \\
\hline $\begin{array}{l}\text { Kurang } \\
\text { Rp.500.000) }\end{array}$ & 20 & 14 \\
\hline $\begin{array}{l}\text { Cukup (Rp. 500.000- } \\
\text { Rp.600.000) }\end{array}$ & 93 & 66 \\
\hline Baik(>Rp. 600.000) & 27 & 19 \\
\hline Total & 140 & 100 \\
\hline
\end{tabular}

Tabel 1 menunjukkan mayoritas responden berusia 16 tahun ke bawah sebanyak 54\%. Dan dari tingkat pendidikan mayoritas berada pada tingkat SMA/K sebedar $61 \%$. Serta mayoritas responden berada pada sosial ekonomi cukup (indikator jumlah kiriman 500.000-600.000) sebesar 66\%. 
Tabel 2 Faktor Determinan Anemia Santri Pondok Pesantren Salafiyah Syafi'iyah Sukorejo Situbondo

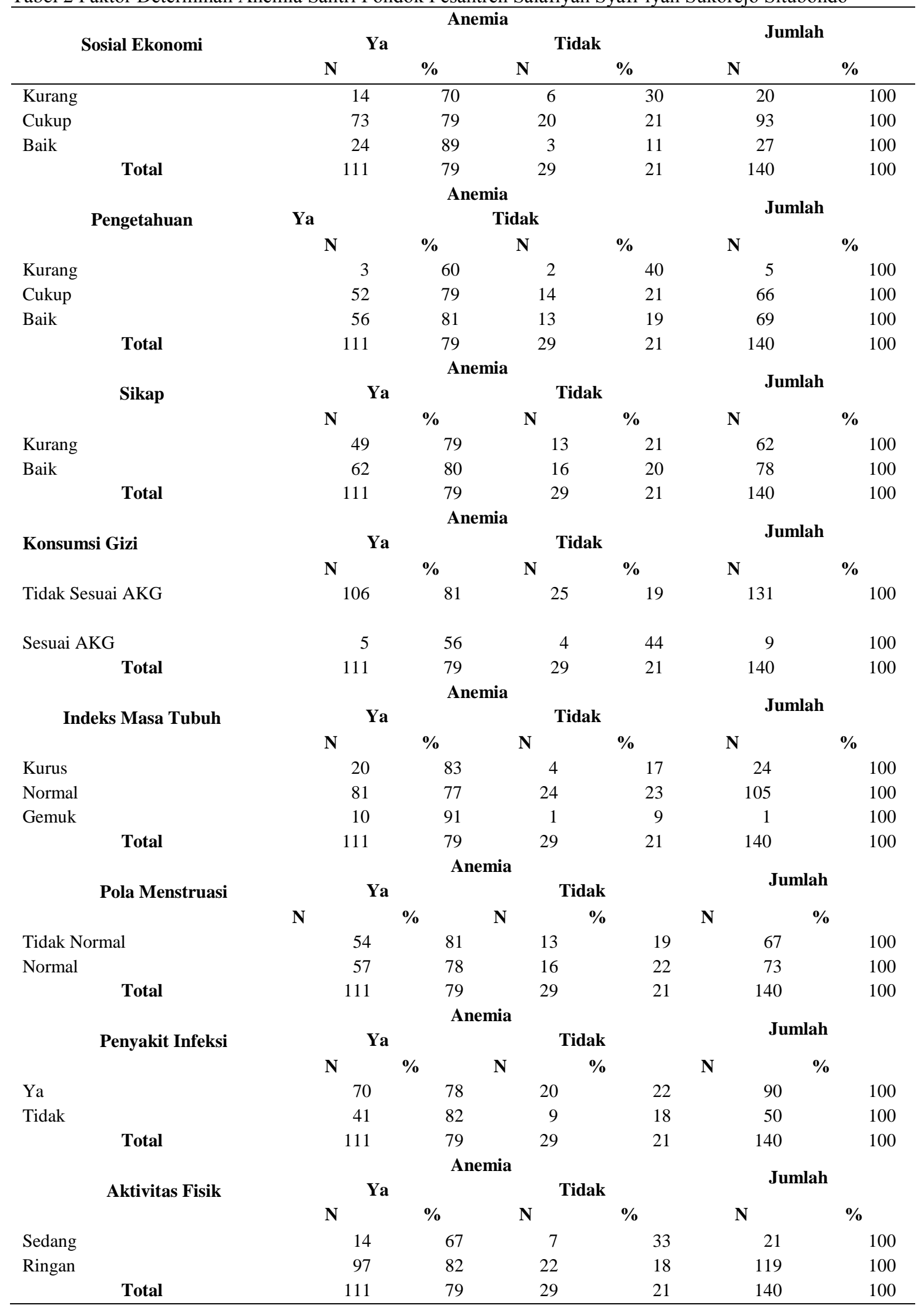


Berdasarkan Tabel 2 menunjukkan bahwa mayoritas santri memiliki pengetahuan yang baik tentang anemia sebesar $49 \%$ dan sebagian kecil yang memiliki pengetahuan kurang tentang anemia sebesar 4\%. Dari aspek sikap, mayoritas santri memiliki sikap cukup tentang anemia sebesar $56 \%$ akan tetapi tidak ada yang memiliki sikap baik terhadap anemia sebesar $0 \%$. Sebagaimana menurut Notoatmodjo (2010), pengetahuan dan sikap memiliki peran yang siginifikan dalam menentukan tindakan seseorang. Begitu pula santri yang memiliki pengetahuan baik dan sikap cukup, diharapkan dapat memiliki tindakan yang positif dalam upaya pencegahan dan penanggulan anemia bagi remaja.

Dari aspek pola makan, mayoritas santri memiliki pola makan yang tidak menentu sebesar $42 \%$ dan sebagian kecil makan 3 kali hingga lebih dalam sehari. Sedangkan dari aspek konsumsi gizi dalam menunjang $\mathrm{HB}$, mayoritas santri belum sesuai konsumsi gizi untuk produksi HB (protein, vitamin A, vitamin $\mathrm{B} 6$, vitamin $\mathrm{C}$, vitamin $\mathrm{E}, \mathrm{Fe}$ ) harian dilihat dari standar angka kebutuhan gizi per jenis kelamin dan usia berdasarkan recall gizi sebanyak $94 \%$.
Banyaknya santri yang belum memenuhi kebutuhan gizi harian dalam upaya pembentukan HB diindikasikan karena beberapa faktor yaitu santri mendapatkan konsumsi hariannya dari membeli makanan di kantin dan pasar yang menyediakan makanan yang sudah masak khsusus santri.

Berbeda dengan pesantren lainnya, di Pondok Pesantren Salafiyah Syafi'iyah dalam hal makanan tidak seragam atau sentral dari kantin, akan tetapi santri bebas membeli di kantin pesantren ataupun pasar pesantren yang keamanan pangannya dipantau oleh pesantren. Sehingga, santri makan sesuai keinginannya. Ada yang $3 x$ sehari, 2x sehari bahkan hanya $1 \mathrm{x}$ sehari. Berdasarkan penuturan responden, mereka lebih sering makan 2x hingga 1x sehari karena malas mengantri. Mereka lebih memilih membeli camilan siap saji yang mengeyangkan seperti pentol, gorengan dan bakso.

Sebagaimana menurut penelitian sebelumnya, remaja yang terbiasa megalami anemia akan mengalami anemia juga pada saat hamil kelak. Sehingga, butuh kontroling dari pihak pesantren untuk memastikan santri dapat memenuhi kebutuhan gizi 
hariannya dari aspek frekwensi dan kualitas makanannya untuk mencegah kejadi anemia.

Dari aspek Indeks Massa Tubuh (IMT), mayoritas santri memiliki IMT normal sebanyak $75 \%$ dan sebagian kecil memiliki IMT gemuk sebanyak $8 \%$. Berdasarkan pola menstruasinya, mayoritas santri memiliki pola menstruasi yang normal sebanyak $52 \%$. Sedangkan dari aspek penyakit infeksi, mayoritas santri mengidap penyakit infeksi selama satu bulan terakhir sebanyak $64 \%$.

Pada aktivitas fisik, mayoritas santri memiliki aktivitas fisik dalam kategori ringan yaitu sebesar $85 \%$. Aktivitas fisik diukur berdasarkan hasil perhitungan rata-rata aktivitas selama $2 \times 24$ jam dengan menggunakan standar kelipatan metabolik National Research Council, National Academy of Sciences yaitu 1, 1,5, 2,5, 5 dan 7, kemudian dikategorikan menjadi 3 yaitu ringan, sedang dan berat.

Secara umum, mayoritas aktivitas santri hanya $2 \mathrm{x}$ sekolah dalam sehari yang jaraknya tidak kurang dari 300M ataupun mengelililingi sekitar asrama saja. Selain itu, aktivitas lainnya hanya duduk saat pengajuan, di asrama ataupun tidur. Sehingga bila disinkronkan dengan kebutuhan harian gizi secara umum tidak defisit akan tetapi jika dibandingkan dengan kebutuhan ideal dari masing-masing kandungan zat gizi masih jauh dari kata standar. Sehingga kejadian anemia menjadi sangat tinggi. Sebagaimana hasil penelitian ini menunjukkan mayoritas santri yang menderita anemia sebanyak $79 \%$.

\section{SIMPULAN DAN SARAN}

Mayoritas santri menderita anemia sebesar 79\%. Dengan 3 faktor determinan penyebab anemia tertinggi adalah konsumsi gizi santri mayoritas tidak sesuai AKG sebesar 94\%, mengidap penyakit infeksi sebesar $64 \%$ serta aktivitas fisik santri mayoritas dalam kategori ringan sebesar $85 \%$.

\section{DAFTAR PUSTAKA}

Almatsier, S., 2009. Prinsip Dasar Ilmu Gizi. Jakarta: Gramedia.

Amran, Y., 2012. Analisis Data. Jakarta: UIN Syarif Hidayatullah Jakarta.

Antelman, G. e. a., 2000. Nutritional Factor and Infectious Disease Contribute to Anemia among Pregnant Woment with Human Immunodeficiency Virus in Tanzania. Am $J$ Clin Nutr, Volume 19, pp. 50-51.

Astuti, R. \& Rosidi, A., 2014. Faktor Risiko Anemia pada Siswa Pondok Pesantren. Semarang, 
The 2nd University Reasearch Coloquium.

Asyiqin, M. Z. \& al., e., 2015. FaktorFaktor yang Menyebabkan Kejadian Anemia pada Santriwati di Pondok Pesantren Miftahul Ulum Kaliwates Jember. Jember: Universitas Muhammadiyah .

Bhagarva, A. \& et.al., 2001. Dietary Intakes and Socioeconomic Factors are Associated with The Hemoglobin Concentration of Bangladesh Women. Am J Clin Nutr, Volume 131, pp. 758-764.

Engel, J. e. a., 1994. Perilaku Konsumen. Jakarta: Binarupa Aksara.

Farida, I., 2007. Determinan Kejadian Anemia Pada Remaja Putri Di Kecamatan Gebog Kabupaten Kudus. Tesis ed. Semarang: Universitas Diponegoro.

Gunatmaningsih, D., 2007. FaktorFaktor yang Berhubungan dengan Kejadian Anemia pada Remaja Putri di SMAN 1 Kecamatan Jati Barang Kabupaten Brebes. Semarang: Universitas Negeri Semarang.

Harper \& et.al., 1986. Pangan, Gizi, dan Pertanian (Suhardjo, Penerjemah). Jakarta: UI Press.

Harsono, 2017. Cupri Sulfat. [Online] Available at: https://www.academia.edu/2553 6466/Cupri_sulfat_Hema_Ardi [Accessed 4 Desember 2017].

Kanani, S. \& Poojara, R., 2000. Suplementation with Iron and Folic Acid Enhances Growth in Adolescent Indian Girls. Am J Clin Nutr, Volume 130, pp. 452S-453S.
Kemenkes RI, 2013. Laporan Hasil Riset Kesehatan Dasar 2013. Jakarta: Litbang Kemenkes RI.

Kemenkes RI, 2013. Profil Kesehatan Indonesia. Jakarta: Pusat Data dan Informasi Kemenkes RI

Lemeshow, S., 1998. Besar Sampel dalam Penelitian Kesehatan. Gajah Mada University Press: Yograkarta.

Listiana, A., 2016. Analisis FaktorFaktor yang Berhubungan dengan Kejadian Anemia Gizi Besi pada Remaja Putri di SMKN 1 Terbanggi Besar Lampung Tengah. Jurnal Kesehatan Politeknik Kesehatan Tanjung Karang, 7(3), pp. 455469.

Lynch, S., 2000. The Potential Impact of Iron Suplementation During. Am. J. Clin. Nutr, Volume 130, p. $488 \mathrm{~S}$.

Madrie, 1981. Beberapa Faktor yang Berpengaruh dengan Sikap Masyarakat terhadap Keluarga Berencana di Lampung. Tesis ed. Bogor: IPB.

Mazrizal, 2007. Anemia Defisiensi Besi. Jurnal Kesehatan Masyarakat FK Unand, 2(1).

Notoatmodjo, S., 2010. Promosi dan Perilaku Kesehatan. Jakarta: Rineka Cipta.

Sanjur, D., 1982. Social and Cultural Prespectif in Nutrition. New York: Prentice Hall.

Sediaoetomo, A., 1992. Ilmu Gizi untuk Mahasiswa dan Profesi. I ed. Jakarta: Dian Rakyat.

Supariasa, 2002. Penilaian Status Gizi. Jakarta: EGC.

Yip, R., 1998. The Challenge of Improving Iron Nutrition. European Journal of Clinical Nutrition. 